\title{
A world apart: The disadvantage and social isolation of married adolescent girls
}

Nicole Haberland

Population Council

Erica Chong

Population Council

Hillary J. Bracken

Population Council

Follow this and additional works at: https://knowledgecommons.popcouncil.org/departments_sbsr-pgy

Part of the Family, Life Course, and Society Commons, Gender and Sexuality Commons, and the International Public Health Commons

How does access to this work benefit you? Let us know!

\section{Recommended Citation}

Haberland, Nicole, Erica Chong, and Hillary J. Bracken. 2004. "A world apart: The disadvantage and social isolation of married adolescent girls," brief based on background paper prepared for the WHO/UNFPA/ Population Council Technical Consultation on Married Adolescents. New York: Population Council. 


\section{A world apart:}

The disadvantage and social isolation of

\section{married adolescent girls}

Excerpted from a paper by

Nicole Haberland

International Programs Division

Population Council

nhaberland@popcouncil.org

Erica L. Chong

International Programs Division

Population Council

echong@popcouncil.org

Hillary J. Bracken

International Programs Division

Population Council

hbracken@popcouncil.org

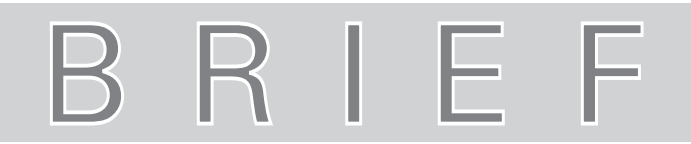


This brief is based on a background paper prepared for the WHO/UNFPA/Population Council Technical

Consultation on Married Adolescents, held in Geneva, Switzerland, 9-12 December 2003. The Consultation brought together experts from the United Nations, donors, and nongovernmental agencies to consider the evidence regarding married adolescent girls' reproductive health, vulnerability to HIV infection, social and economic disadvantage, and rights. The relationships to major policy initiatives_-including safe motherhood, HIV, adolescent sexual and reproductive health, and reproductive rights—-were explored, and emerging findings from the still relatively rare programmes that are directed at this population were discussed. The meeting and specific papers were supported in part by funding from The Ford Foundation, the Bill \& Melinda Gates Foundation, The John D. and Catherine T. MacArthur Foundation, the Population Council, U.K. Department for International Development, UNFPA, and WHO.

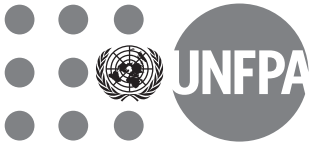

The United Nations Population Fund (UNFPA) supports developing countries, at their request, to improve access to and the quality of reproductive health care, particularly family planning, safe motherhood, and prevention of sexually transmitted infections including HIV/AIDS. Priorities include protecting young people, responding to emergencies, and ensuring an adequate supply of condoms and other essentials. The Fund also promotes women's rights and supports data collection and analysis to help countries achieve sustainable development. About a quarter of all population assistance from donor nations to developing countries is channelled through UNFPA, which works with many government, nongovernmental organisation, and United Nations partners.

\section{(2) Population Council}

This document is not a formal publication of the United Nations Population Fund. The opinions expressed herein are those of the author(s) and do not necessarily reflect the views of UNFPA.

Suggested citation: Haberland, Nicole, Erica L. Chong, and Hillary J. Bracken. 2004 "A world apart: The disadvantage and social isolation of married adolescent girls," brief based on background paper prepared for the WHO/UNFPA/Population Council Technical Consultation on Married Adolescents. New York: Population Council. 


\section{INTRODUCTION}

Despite the programme attention and funding that have been devoted to adolescents, early marriage and married adolescents have fallen largely outside of the field's concern. Comprising the majority of sexually active adolescent girls in developing countries, this large and vulnerable subpopulation has received neither programme and policy consideration in the adolescent sexual and reproductive health field, nor special attention from reproductive health and development programmes for adult women. While adolescent girls, irrespective of marital status, are vulnerable in many settings and deserve programme, policy, and resource support, the purpose of this brief is to describe the distinctive and often disadvantaged situations of married girls and to propose possible future policy and programme options.

\section{Married adolescent girls are a large and neglected group}

Although age at marriage in the developing world is increasing with few exceptions (Mensch 2003), the number of individuals affected by early marriage remains large. In the next ten years, if current patterns continue, over 100 million girls will be married before the age of 18 , that is, as "children," as defined by the Convention on the Rights of the Child (2002 analysis of UN country data on marriage, Population Council). ${ }^{1}$

Generally, the countries with the highest proportion of girls married before their eighteenth birthday are found in West Africa and South Asia. Thus in Bangladesh, Burkina Faso, India, Mali, and Nepal, half or more than half of girls currently aged 20-24 were married by age 18 (see Table 1). Relatively high proportions of early marriage also exist in other countries: for example, in the Dominican Republic, Ethiopia, and Nigeria between 38 percent and 49 percent of girls aged 20-24 were married before their eighteenth birthday. Moreover, national-level figures often mask considerable variation. Pockets of early marriage exist in most countries, defined by region, ethnic or religious group, or economic disadvantage. In some areas, a large proportion of girls continue to be married before their fifteenth birthday-50 percent of girls in
Amhara, Ethiopia; 40 percent in Bihar, India; and 25 percent in Jinotega, Nicaragua. ${ }^{2}$

Married girls are of concern because of both their substantial numbers and their vulnerability. Indeed, in the vast majority of developing countries, most sexual activity among adolescent girls takes place in the context of marriage (Bruce 2002). Moreover, married girls are more likely than unmarried girls to have unprotected sex. Indeed, in a review of DHS data from 31 countries, on average 80 percent of unprotected sexual acts among 15-19-year-old girls occur within marriage (Bruce and Clark 2003). The frequent occurrence of unprotected sex among married girls reflects in part the continued importance of childbearing in elevating a girl's status in the household, and the often intense pressure to prove one's fertility. Thus, while age of marriage is increasing in the developing world, the average number of months between marriage and first birth is actually declining (Mensch 2003). Across regions, 90 percent of first births to girls younger than age 18 occur within marriage (2004 analysis of DHS data by Monica Grant, Population Council). ${ }^{3}$

\section{Child marriage is a violation of human rights}

In accordance with the Convention on the Rights of the Child (CRC), which defines age 18 as the upper boundary of childhood, there is an emerging international consensus that marriage before age 18 is child marriage. Of the 126 countries that have ratified or signed the Convention on the Elimination of All Forms of Discrimination Against Women (CEDAW) and have established minimum ages of marriage, 69 percent set the age at 18 or above, and 64 percent set the same minimum age for girls as that for boys (International Planned Parenthood Federation and International Women's Rights Action Watch 2000). Several countries have set a higher legal age: El Salvador, Ghana, Rwanda, and Zambia, for instance, have set the minimum age at 21 for females and males. Of course, laws are only as strong as the ability and will to enforce them; and, in some settings, religious or traditional practices or caveats for parental or judicial consent supersede or permit circumvention of civil legislation.

Early marriage is a violation of several international agreements, including the Universal Declaration of Human

1 Marriage among adolescent boys is much less common. According to Demographic and Health Survey data, in contrast to females, the vast majority of males marry after age 20 .

2 All data in this paragraph are based on DHS from 1996 to 2001, calculated among 20-24-year-old females.

3 This statistic is calculated among 20-24-year-olds, weighted regionally, from 51 recent DHS (1991-2002) representing 60 percent of the developing world's population. Looking regionally, the proportion varies from 73 percent in East and Southern Africa to 98 percent in West Asia and North Africa. 
TABLE 1. Proportions of 20-24-year-old girls married by ages 15 and 18 and median age at marriage of 20-24-year-old girls in selected settings (DHS data)

\begin{tabular}{lccc} 
Country, region & Married by $\mathbf{1 5}(\%)$ & Married by $\mathbf{1 8}(\%)$ & Median age at marriage (years) \\
\hline Burkina Faso 1998-99 & 8 & 62 & 17.6 \\
$\quad$ East & 10 & 70 & 17.4 \\
\hline Ethiopia 2000 & 19 & 49 & 18.1 \\
$\quad$ Amhara & 50 & 80 & 15.0 \\
Affar & 20 & 70 & 16.2 \\
\hline Mali 2001 & 25 & 65 & 16.7 \\
$\quad$ Kayes & 39 & 83 & 15.5 \\
Koulikoro & 32 & 79 & 15.8 \\
\hline Nigeria 1999 & 20 & 40 & 19.6 \\
Northeast Region & 42 & 69 & 15.5 \\
$\quad$ Northwest Region & 48 & 78 & 15.1 \\
\hline India 1998-99 & 24 & 50 & 18.0 \\
Rajasthan & 36 & 68 & 16.0 \\
Bihar & 40 & 71 & 15.7 \\
Uttar Pradesh & 36 & 62 & 16.2 \\
\hline Nepal 1996 & 19 & 60 & 17.1 \\
$\quad$ Far-western region & - & - & 15.9 \\
\hline Bangladesh 1999-2000 & 38 & 65 & 16.1 \\
Rajshahi division & - & - & 15.1 \\
Khulna division & - & - & 15.4 \\
\hline Dominican Republic 1996 & 11 & 38 & 19.5 \\
Enriquillo & 18 & 54 & 17.7 \\
El Valle & 19 & 56 & 17.5 \\
\hline Nicaragua 1998 & 16 & 50 & 17.0 \\
Jinotega & 25 & 67 & 17.2 \\
RAAN (Región autónoma atlántico norte) & 19 & & \\
\hline
\end{tabular}

Rights (1948, article 16); the Convention on Consent to Marriage, Minimum Age for Marriage and Registration of Marriages (1962, article 1); the International Covenant on Civil and Political Rights (1966, article 23); CEDAW (1979, article 16.1.b); CRC (1989); and the African Charter on the Rights and Welfare of the Child (1990, article XXI). The right to enter a marriage only with the "free and full consent" of both parties looms large in some of these legal pronouncements, codifying women's right to

4 Several issues underlie this situation. When there is no real option of refusal, a young woman's assent to marriage can perhaps be more aptly characterized as submission or "habitual acquiescence" than genuine consent (Carole Pateman uses the term "habitual acquiescence" in an essay examining women, consent, and liberal democracy [Pateman 1980, p.150]). The issue of consent is further confounded when marriage and motherhood (and, to a lesser degree, marriage and fatherhood) is the path taken with the fewest excep- have a say in when and whom she marries. One can argue that a girl under age 18-particularly in contexts where girls and women have a limited say in decisionmaking in general, and where marriage is nearly universal—even if she is asked whether she agrees to a marriage, may have little real choice, thus violating her right to consent. ${ }^{4}$ Despite this limitation, consent remains an important-if underutilized-safeguard. The challenge is to make the consent more authentic, by delaying marriage and by expanding the

tions. Moreover, even if girls and boys agree to marriage, are they capable of consenting given their level of cognitive development? The CRC acknowledges the "evolving capacities" of the child to consent; however, given the context in which early marriage takes place, the life-changing nature of marriage, and the consequences to physical and mental health, the presumption should be that a child under the age of 18 does not have the capacity to consent to marriage (Laura Katzive, personal communication, 2003). 
idea of consent to give it more meaning and value, particularly in the context of arranged marriages (Sajeda Amin, personal communication, 2004; see also discussion below on arranged marriages).

The CRC looks beyond issues of consent and centers attention on the rights that are circumscribed or precluded for girls upon marriage. These include not being separated from her parents against her will (article 9), the right to freedom of expression (including seeking and receiving information and ideas, article 13), the right to education (articles 28 and 29), the right to rest and leisure and to engage in play and recreational activities (article 31), and the right to protection from sexual exploitation and abuse (article 34). Yet the CRC explicitly includes a caveat: The eighteenth birthday is the upper boundary of childhood “... unless, under the law applicable to the child, majority is attained earlier" (article 1). Individual countries may thus decide whether marriage confers majority and thus removes a girl (or boy) from the protections of the CRC.

\section{THE TRANSITION TO MARRIAGE: A CONFLUENCE OF PROFOUND CHANGES}

Rather than a simple change in status from unmarried to married, marriage is a process that changes virtually all the known and safe parameters of girls' lives. ${ }^{5}$ Typically, girls who marry are moved from their familiar home and village, lose contact with friends, initiate sexual activity with someone they barely know, and soon become mothers. Because of their young age, these girls may find themselves particularly isolated and may have less power to negotiate a state of affairs with which they can feel safe and comfortable. We cannot determine from the cross-sectional data available whether early marriage causes social or health disadvantages. Findings, however, suggest that independent of other factors, girls (compared to older women), or girls and women who were married at a young age (compared to women married at a later age), may experience less domestic power, less freedom of movement, and more partner violence (Jejeebhoy 2000; Kishor 2000; Kishor and Johnson 2004;

Mason 1998).

The degree to which a young woman has a say in the timing of her marriage or choice of spouse varies from setting to setting. Some studies on women's empowerment have found that say in selecting a spouse may be independently associated with some indicators of empowerment and reproductive health (Gage 1995; Kishor 2000). In settings where most marriages are arranged_-and in many countries of South Asia, the Middle East, and Africa arranged marriages continue to be the norm-in effect it can be the parents or other relatives who determine when a girl initiates sex and with whom. In a qualitative study in Senegal, a married girl recalls, "Me, I was given in marriage without anyone asking my opinion. I always must submit to the wish of my father" (Diop and N'Dione 2001). While there are limited large-scale data sets that include variables on spousal selection, some indicate that the younger the age at marriage, the lower the proportion of females who had a say in selecting their spouse (El-Zanaty et al. 1996) or the lower the proportion of females who were asked for their consent (Amin 2004). Nevertheless, the institution of arranged marriages is not static and absolute. A young woman may not have chosen her spouse per se but may have had some say in the selection. ${ }^{6}$

Indeed, among certain groups the institution of arranged marriage is evolving to play a facilitating rather than a prescriptive role in matching a couple (Sajeda Amin, personal communication, 2004).

The husbands of young women are usually significantly older, may be unknown to the women, and may be less healthy than younger men. In general, the younger a girl's age at marriage, the greater the age difference between her and her husband (Mensch 2003; Mensch, Bruce, and Greene 1998). Some girls never meet their prospective

5 We note here that in some settings, particularly in sub-Saharan Africa, the clear delineation - by a ceremony or legal documentof typical Western marriages does not hold (Ngondo a

Pitshandenge 1994). Instead, marriage is more typically a process with several stages including betrothal/promising, granting of sexual rights/initiation of sexual relations, the start of cohabitation, and a ceremony or celebration, all of which can occur in different sequence and last for different durations (Meekers 1992; van de Walle and Meekers 1994). Thus in some settings sexual intimacy begins before marriage is formally recognized. In such contexts, married/unmarried distinctions may be an inadequate variable for understanding complex relations and processes.

6 In the majority of instances "choice in spouse" is not a yes/no answer, rather, "[i]n actuality, totally arranged and completely self-chosen marriages represent only two extremes of a continuum; individuals in most societies marry with varying degrees of input somewhere between the two" (Malhotra 1991, p. 550; also see Gage-Brandon and Meekers 1993). A recent qualitative study in three localities in Egypt finds that female wage laborers exercised considerable say in the arranged marriage process (Amin and Al-Bassusi, in press). 
spouse, or meet him only briefly before the wedding. In an intervention study in India that surveyed over 2,100 married girls and young women, 69 percent of girls in Vadodara, Gujarat, and 80 percent of girls in South 24 Pargana, West Bengal, had never met their husband before they were married (Santhya et al. 2003). In qualitative research for the same project, a girl from Vadodara, Gujarat, stated, "My mother and brothers will not do any bad for me. They will select a good boy only. I don't need to see or meet the boy" (Haberland, McGrory, and Santhya 2001). In settings where marriage to relatives is common, it is possible that a girl may know her husband before marriage, but this is not necessarily the case. The 1995 Egypt DHS, for example, found that among females who did not choose their husbands, one-third of females marrying relatives had not met their husband or had not met him alone before marriage (El-Zanaty et al. 1996). Finally, husbands are more likely to be older than partners of unmarried adolescent girls, and, by virtue of their age, may be more likely to be infected with HIV (Bruce and Clark 2003).

Marital transactions-a transfer of money, goods, or services from the groom's family to the bride's (bridewealth) or from the bride's family to the groom's (dowry) — are a feature of marriage in many developing countries. The particular nature of the transaction (for instance, payments that accrue mostly to the groom's family, or intergenerational transfers of wealth to help the young couple set up their household) is thought to interact with poverty in different settings to delay or hasten the timing of marriage (Caldwell, Reddy, and Caldwell 1983; Schuler, Hashemi, and Badal 1998, Singerman and Ibrahim 2001), but there is little empirical evidence to support this. One exception is research by Amin, Mahmud, and Huq (2002) that found a clear association between age at marriage and dowry in rural Bangladesh: Dowry is higher for girls who marry when they are older. In some settings the transaction may increase a married female's risk of domestic violence. In Bangladesh, where the groom's family receives a dowry, Suran and Amin (2004) found that after controlling for confounding variables, currently married female respondents aged 15-24 who paid dowry were significantly more likely to report being abused (mostly by husbands) in the past year (OR=1.55; $\mathrm{p}=0.01$ ) than those who did not pay dowry; and among women who paid dowry, those who made payments after marriage had an even greater likelihood of having been beaten $(\mathrm{OR}=6.62 ; \mathrm{p}=0.01)$.
Marriage marks the transition to becoming sexually active for many girls. This sex is often unsafe and girls are not adequately prepared for it. In a qualitative study in Mumbai, India, women described their sexual initiation in a variety of overlapping ways, including unexpected, embarrassing, frightening, painful, or inevitable (George 2002). A woman who was married as a girl described the event with these words:

\section{A fear was born in me, if I don't allow him to do it,} who knows, he may kill me. There was a kind of fear in my heart. I felt nothing, I thought, go on, do

whatever you want to do. (George 2002)

In many developing-country settings, a female goes to live in her husband's or husband's family's home once married. Contact with old friends is often severed, and social interactions are primarily with the girl's marital family or individuals sanctioned by her in-laws. This move to the husband's home is a move into the marital family hierarchy. Whether a girl moves into an extended or a nuclear marital family may also have implications. For instance, in Egypt Kishor (2000) finds that living with in-laws — currently as well as during the early years of marriage- - has a negative effect on women's empowerment and, in turn, on child health outcomes. The relationship between household structure and spousal abuse does not appear to be consistent between countries. In a nine-country analysis of DHS data, researchers found upon multivariate analysis that in the Dominican Republic and India a woman's odds of currently experiencing spousal violence are significantly higher if she lives in a nuclear household, whereas no significant difference was found in Colombia, Egypt, Haiti, Nicaragua, or Zambia (Kishor and Johnson 2004). Women's status in polygynous marriages - found mostly in sub-Saharan Africa-is affected not only by the wife's position vis-à-vis her husband, but also by her position vis-à-vis other co-wives (Gage-Brandon and Meekers 1993). In a qualitative study in Burkina Faso, a 17-year-old married girl said, "I don't talk much because I belong to him and I am the youngest wife" (Saloucou, Kabore, and Traore 2002).

\section{MARRIED ADOLESCENT GIRLS: A WORLD APART}

While there is romantic imagery associated with being a young married woman, there has been little empirical investigation of how marriage affects girls. We thus cannot, 
for the most part, determine causality with existing studies and data. However, we can look more closely at outcomes: specifically how married girls fare when compared to unmarried girls or to married young women.

Recent findings ${ }^{7}$ indicate that married girls:

- consistently have less education and fewer schooling opportunities than unmarried girls;

- have less mobility than their unmarried counterparts and married young women;

- have less household and economic power than older married women;

- have less exposure to modern media than unmarried girls;

- have limited social networks;

- may be at greater risk of gender-based violence than females who marry later; and

- possibly face greater reproductive health risks than their unmarried counterparts and married young women who have already had a child.

Regardless of whether girls who are more vulnerable are married early or whether early marriage itself creates some of the vulnerability, the fact is that this "presenting client" - that is, the married girl—has special needs and circumstances, whatever the underlying determinants.

\section{Married girls consistently have less education and fewer schooling opportunities}

Education is desirable in and of itself. It is also a right under the CRC (articles 28 and 29). Education expands knowledge and provides tools to function in a modern world. As an independent variable, it is consistently and positively linked with women's reproductive health, sexual negotiating ability, and infant mortality and autonomy outcomes (Jejeebhoy 1995; Wolff, Blanc, and Gage 2000).

Across regions, the percentage of women married by age 18 decreases with increasing years of schooling (Mensch

2003). For instance, Mensch finds that among women aged 20-24 in South and Southeast Asia, the proportion married by age 18 is 17.3 percent among those with eight or more years of schooling and 55.7 percent among those with $0-3$ years of schooling. Similarly in West and Central Africa the proportion is 14.1 percent among women with eight or more years of schooling and 70.5 percent among those with 0-3 years of schooling. In South America the corresponding figures are 10.8 percent and 41.7 percent (Mensch 2003). These differences exist at the country level as well.
Married girls appear to have less mobility than their unmarried counterparts or married young women

Women's mobility—often measured by whether a woman can go unescorted to selected places-is a frequently used indicator of women's empowerment. A survey in rural Bangladesh including 2,544 girls aged 13-22 found that married girls have less freedom of movement than unmarried girls (Amin, Mahmud, and Huq 2002). ${ }^{8}$ While 31.7 percent of unmarried girls were allowed to visit other neighborhoods, only 24.1 percent of married girls could; and 9.5 percent of unmarried girls were allowed to go to a tea stall versus 3.2 percent of married girls. In Kenya, Erulkar and Onoka (2003) surveyed over 2,700 young people in Nyeri and Nyandarua. Preliminary findings indicate that a higher proportion of unmarried girls and of young women married after age 20 went to a restaurant, a bank, or a post office in the last week as compared with girls married during adolescence $(\mathrm{p}<0.001$ for each variable).

Using a mobility index, a study in South 24 Pargana, West Bengal, India, found that 71 percent of married adolescents compared to 58 percent of married young women had no freedom of mobility (Santhya et al. 2003). This increased restriction of mobility is also evident in the 1998-99 National Family Health Survey (NFHS) in India. The proportion of married girls aged 15-19 who are able to go to the market without permission is about half that of married 20-34-year-olds (13.8 percent vs. 28.1 percent). The same is true for the proportion not needing permission to visit friends (10.2 percent of 15-19-year-olds vs. 20.8 percent of 20-34-year-olds) (Santhya and Jejeebhoy 2003).

\section{Married girls have less household and economic power than older married women}

One frequently used measure of a woman's power is the degree to which she has input into household decisionmaking —including, for instance, decisions around health care and visiting family, and economic decisionmaking.

Comparing DHS data on married girls younger than 20 years of age with married young women aged 20-24 and 25-29 in Egypt (see Table 2), the majority of married young women have no input into final decisions regarding

7 The following draws mostly from large-scale or nationally representative surveys, but some data also come from smaller and/or qualitative studies that have limited representativeness; these are indicated accordingly.

8 Of the total sample of girls, 51 percent were ever married. 
TABLE 2. Participation in decisionmaking among currently married girls/women aged 15-29 years in Egypt (DHS data)

\begin{tabular}{lccc} 
Respondent has some part in final say on & $15-19$ years & $20-24$ years & $25-29$ years \\
\hline Visiting friends and family (\%) & 22 & $33^{* * *}$ & $39^{* * *}$ \\
Type of food cooked in house (\%) & 63 & $74^{* *}$ & $82^{* * *}$ \\
\hline
\end{tabular}

Note: Comparisons for statistical significance are between 15-19- and 20-24-year age groups, and 15-19- and 25-29-year age groups.

** Significant at $\mathrm{p}<0.01$. ${ }^{* * *}$ Significant at $\mathrm{p}<0.001$.

visiting friends and family, but younger girls are even less likely to have some part in the final say regarding household decisions.

As with household decisionmaking in general, married girls appear to be less involved than married young women in decisions regarding economic resources, and they have less access to money. In Nyeri and Nyandarua, Kenya, preliminary findings indicate that married girls younger than age 20 were less able to influence decisions regarding the household budget than were married young women (66.7 percent vs. 81.1 percent; $\mathrm{p}<0.01$ ) (Erulkar and Onoka 2003). And in India, 45.6 percent of married girls 15-19 years old had access to cash, compared to 58.1 percent of young women aged 20-34 (Santhya and Jejeebhoy 2003). These differences were more marked in urban (55.0 percent vs. 72.3 percent) than in rural areas ( 44.0 percent vs. 53.2 percent) and were evident regardless of employment status (e.g., of those working for pay, 45.0 percent of 15-19-year-olds vs. 61.5 percent of 20-34-year-olds had access to money) (Santhya and Jejeebhoy 2003).

\section{Married girls have less exposure to modern media}

A woman's exposure to media can link her to modern messages and influences and inherently determines the degree to which she hears or sees information campaigns about, for instance, HIV/AIDS or family planning. It also shapes attitudes and expectations and may be associated with increased empowerment (Kishor 2000).

Results from a nationally representative 2003 survey of young people ages 14-22 in Nepal indicate that 47.3 percent of unmarried girls watched television, listened to the radio, or read a newspaper daily compared to only 28.3 percent of married girls. ${ }^{9}$ In rural Bangladesh, Amin, Mahmud, and Huq (2002) found that 40.1 percent of unmarried girls listened to the radio compared to only 26.5 percent of mar- ried girls. Similarly, 51.8 percent of unmarried girls versus 23.4 percent of married girls watched television. In a preliminary analysis of data from Nyeri and Nyandarua, Kenya, Erulkar and Onoka (2003) found that 38.5 percent of girls married during adolescence read a newspaper, as compared to 44.2 percent of girls married after age 20 and 59.0 percent of unmarried girls $(\mathrm{p}<0.001)$. The same pattern holds for exposure to television and radio.

\section{Married girls have limited social networks}

Development programmes, credit groups, and other activities as well as nonfamilial peers and mentors can significantly shape a person's experiences and options. ${ }^{10}$ Exposure to peers, professionals, and other non-kin may allow social learning and openness to change (Madhavan, Adams, and Simon 2003).

Early marriage typically cuts girls off from established support networks and friends. A move to her husband's home is often entailed, as is a new code of deportment. In sites in rural Bangladesh, Amin, Mahmud, and Huq (2002) found that 88.8 percent of unmarried girls reported having many friends in the area compared to only 40.5 percent of married girls. No significant difference was found in girls' involvement in clubs. In Vadodara, Gujarat, India, Santhya and colleagues (2003) found that 96 percent of respondents reported having friends in their natal home, but only 25

9 Data for all Nepal are supplied by Shyam Thapa (personal communication, 2004). For results based on the urban sample of the survey see Thapa and Mishra 2003.

10 For example, studies in rural Bangladesh found that participation in credit groups increased women's empowerment and reduced their likelihood of being beaten, and that some programmes were positively associated with contraceptive use (Hashemi, Schuler, and Riley 1996; Schuler and Hashemi 1994; Schuler et al. 1996; Steele, Amin, and Naved 2001). 
percent reported having friends in their marital home. In South 24 Pargana, West Bengal, the figures were 67.3 percent and 6.8 percent, respectively. Only a very small percentage of married girls were members of a group or club (1.8 percent in Gujarat and 0.7 percent in West Bengal).

\section{Married girls may be at greater risk of gender-based violence}

Gender-based violence has been associated with poor reproductive health outcomes, including HIV infection, and is a serious concern in its own right. While gender-based violence is an issue of acute relevance to adolescents, and violence within marriage is prevalent across regions, there have been no studies specifically examining gender-based violence among married girls. Further research is needed to determine married girls' relative vulnerability to such violence. Married girls may or may not be at greater risk than older married women, but because of their social isolation they may be least well situated to find comfort or support, or ameliorate the abuse or its consequences.

Women's current age and their age at marriage are independently associated with domestic violence in some settings but not in others. In a comprehensive analysis of DHS data from nine countries (Cambodia, Colombia, the Dominican Republic, Egypt, Haiti, India, Nicaragua, Peru, and Zambia) that included questions on domestic violence, Kishor and Johnson (2004) find inconsistent patterns across countries. Controlling for other characteristics, they find that a married woman's age significantly affects her risk of violence in about half the countries, and in these countries (Egypt, Haiti, India, and Nicaragua) girls aged 15-19 are at greater risk of currently experiencing violence than older women. Across almost all countries, the risk of violence decreases with increased age at marriage, and the association between rising age and decreased risk of violence reaches statistical significance in about half the countries (Kishor and Johnson 2004).

\section{Married girls face health risks}

Married girls often are uneducated and from poor households. Poverty and lack of education themselves are risk factors for adverse reproductive health outcomes such as HIV infection and maternal death or illness (Hallman 2004; Miller and Lester 2003). At the same time, married girls are under pressure to become pregnant, with higher sexual frequency when seeking a first birth versus a second or higherorder pregnancy (Bruce and Clark 2003).
First births are riskier than second- or third-parity births for women of any age. The role of age per se is less clear, with the exception of the youngest mothers (i.e., those younger than age 16) whose bodies may not yet be ready for childbearing (Miller and Lester 2003; Beverly Winikoff commentary at WHO/UNFPA/Population Council Technical Consultation on Married Adolescents, 2003). DHS data show that the majority (78 percent) of births to married girls before the age of 18 are first births, and the vast majority ( 90 percent) of first births before age 18 are to married girls, which indicates that the phenomenon of first birth is highly relevant for married adolescent girls (analysis of DHS data by Monica Grant, Population Council, 2004). Some of the specific adverse outcomes associated with first births include pre-eclampsia/eclampsia, prolonged or obstructed labor, and malaria (Miller and Lester 2003). Moreover, babies born to young mothers (particularly those aged 15 and under) are at increased risk of neonatal and infant death (Olausson, Cnattingius, and Haglund 1999; Phipps and Sowers 2002).

Girls married before the age of 18 may face significant risks of acquiring HIV. Crossing the threshold into marriage greatly increases the frequency of unprotected sex, usually with an older partner who, by virtue of his age, may have an elevated risk of being HIV-positive (Bruce and Clark 2003). In an analysis of data from Kenya and Zambia using biomarkers, Clark (2004) calculates that the husbands of married girls are more likely than the boyfriends of unmarried girls to be infected with HIV (30.0 percent vs. 11.5 percent in Kisumu, Kenya, and 31.6 percent vs. 16.8 percent in Ndola, Zambia). ${ }^{11}$

Married girls are frequently at a disadvantage in terms of reproductive health information-particularly regarding sexually transmitted infections and HIV. For instance, a study of 8,084 young people in 20 districts in Indonesia found significantly less knowledge of key reproductive health issues among married girls compared to unmarried girls aged 15-19: 13 percent of married girls versus 31 percent of unmarried girls knew what a condom was, and 59 percent versus 86 percent, respectively, had heard of HIV/AIDS (Achmad and Westley 1999). In addition, younger brides may be less able than older ones to negotiate contraceptive use. In Togo, Gage (1995) found in her

11 For more-detailed discussion of married girls' reproductive and sexual health see Bruce and Clark 2003; Miller and Lester 2003; and Santhya and Jejeebhoy 2003. 
analysis of DHS data that women who married after their eighteenth birthday were 59 percent more likely than those who married before age 16 to discuss family planning with their partners and were 53 percent more likely to have ever used a modern method of contraception.

Access to health care services appears to vary from setting to setting. In an analysis of DHS data from 15 developing countries, researchers found differences between adolescents and older women in antenatal and delivery care in some countries but not in others (Reynolds et al. 2003). In their review of studies from India and analysis of the India NFHS, Santhya and Jejeebhoy (2003) suggest that given the societal value placed on childbearing, it may be that health care needs related to pregnancy and delivery are more quickly addressed than other reproductive health issues such as symptoms of reproductive tract infections or contraception, which "may be more directly linked to the woman's own decision making role in the family" (p. 4375). Moreover, even if access to care is similar for married adolescents compared to older women, the significant deficiencies that have been documented in maternal health services (Khalil 2003; Miller et al. 2003) mean that these services are not adequately meeting the needs of adult women, and perhaps especially failing those of young, firsttime mothers (Miller and Lester 2003).

\section{BREAKING THE CYCLE, SUPPORTING THE VULNERABLE}

Married girls tend to be less mobile, have more limited social networks, have less say in decisionmaking, have less exposure to the media, and have less education than unmarried girls and married young women. They also may be at greater risk of spousal abuse. Whether these disadvantaged outcomes are actually caused by early marriage, or whether more vulnerable girls tend to marry in adolescence, cannot be said from these comparisons. Regardless of the underlying determinants, however, the consistent social disadvantage married girls experience is an issue of deep concern, and there are a large number of girls in this circumstance.

Current policies and programmes either have not considered married adolescent girls or have incompletely appreciated their situation. The assumption in the adolescent reproductive health field has been that married girls are served by established reproductive health services and are privy to information-owing to the social sanction of their "married" status - to which unmarried girls are not. Adolescent sexual and reproductive health programmes have focused, almost without exception, on the unmarried. And while existing reproductive health initiatives have not deliberately excluded married adolescents—indeed, "[m]arried women have always been treated as adults with respect to the delivery of reproductive health information and services, regardless of age" (Gage 2000, p. 190)—in general they also have not mounted concerted efforts to include them. Similarly, many community-based livelihoods and social mobilization programmes directed at women tend to attract older, married women who have children. Without special efforts these programmes do not necessarily reach the newly married. The result is that inadequate policy, research, and programme attention has been paid to married girls.

\section{Policy and programme priorities: Delay age at marriage and support married girls}

The first objective, then, is to delay age at marriage by fostering an environment that is supportive of later marriage and offering families the resources and options they need to defer marriage. Delaying marriage is important not only from a rights perspective, but also because it can be an opportunity to take actions that support unmarried girls in making more successful and empowered transitions to adulthood. Key strategies include rights-based efforts to register marriages and to foster knowledge and enforcement of laws concerning minimum age at marriage.

Governments also need to contend with social and religious caveats such as parental consent exemptions that allow girls and boys to be married below the legal minimum age. Community-based efforts to change norms regarding the age at marriage, such as offering incentives for parents to delay their daughters' marriages until age 18 , have also been tried in some settings. The experience of communitybased efforts to oppose female genital cutting can be instructive, for this practice too has often been rationalized as being part of a culture. Another complementary set of strategies includes those that may contribute to delayed marriage through social or economic pathways such as increasing girls' educational opportunities, social connections, livelihood options, and access to and control of resources.

Two examples from Bangladesh illustrate the potential impact of education and wage earning on the timing of marriage: 
- An innovative educational intervention offers evidence that parents are delaying the marriage of their 11-19-year-old daughters in response to a secondary-school scholarship programme. In this programme monthly stipends are deposited into a girl's bank account if she attends secondary school 65 percent of the time that school is in session and if she maintains a passing grade-point average (Arends-Kuenning and Amin 2000).

- Research indicates that unmarried adolescent girls' participation in wage-earning factory work within the garment industry is delaying marriage. There is evidence that the average age at marriage has increased both among these girls and among nonworking girls who live in the working girls' natal home communities (Amin et al. 1998).

The second objective is to support those girls who are already married by addressing the isolation and disempowerment that characterize their situation as well as their health care needs. Policymakers and programme managers must promote a healthy and positive transition to marriage and motherhood that ensures the well-being of young mothers and their children. This entails, for example, expanding girls' skills, agency, social networks, command over resources, and negotiating power in relationships, as well as making accurate health information and vital reproductive health services more directly accessible to them. Specifically:

- Policies and programmes that facilitate engaged and married girls' return to or continuation in school are needed. Yet there are very few programmes that formally attempt to do this.

- Health strategies to delay the first birth, support first-time mothers, and prevent the transmission of HIV and other sexually transmitted infections can be combined or independently fielded. Promoting condom use in marriage may be more acceptable if it is couched in terms of protecting family health and girls' future fertility (Brady 2003). Tailoring antenatal, delivery, and postpartum services to the needs of young, first-time mothers could go a long way toward improving the health of young brides and their children and may establish beneficial health-seeking behavior, nutrition, infant feeding, and infant care habits that carry over into subsequent pregnancies.

- Married girls typically require the consent or accompaniment of their husband, a parent, or an in-law to go to destinations beyond their neighborhood or compound. Health and social programmes can address the limited mobility of married girls through socially acceptable activities that can get married girls out of the home. Programme managers can also make stronger efforts to bring programmes and services directly to girls, for instance, via home visits or through local-level clinics.

- Increasingly media_radio, television, and billboards - are used to convey messages and diffuse new ideas. These messages reach a relatively small number of married girls, but they are heard by a larger fraction of people who have significant influence over these girls' lives. Thus, while mass media are limited in their ability to reach married girls, policymakers should consider crafting messages to reach parents, husbands, in-laws, and other gatekeepers.

- The limited number of and intensity of contact with friends mean that married girls typically are not being reached by programmes or by the new ideas that can flow via nonfamilial networks and peers. Interventions should make special efforts to create safe, nonfamilial spaces for married girls to interact.

Programme examples—although few and far between-do exist. For instance, the First-Time Parents Project in India comprises three main components: information, augmented reproductive health services, and group formation. Information on a range of sexual and reproductive health issues, including birth spacing, safe delivery, postpartum care, and partner communication, are provided to married girls and their husbands via household visits. To increase girls' connection with nonfamilial peers and mentors and their ability to act on their own behalf, girls who are recently married, pregnant, and postpartum are organized into groups that engage in a range of social and economic activities depending on their self-identified needs and concerns (Santhya and Haberland 2003). In Nigeria, a programme of the Adolescent Health and Information Projects works primarily with married and divorced adolescents to train them in income-generation skills, as well as to provide them with information on health and human rights issues (Graft, Haberland, and Goldberg 2003). These examples of projects for married adolescents are founded on the belief that gender and economic disparities are important to remedy in their own right, and unless the social and economic disadvantages of married girls are addressed, they will not fully benefit from other interventions. 
For both of these objectives-delaying marriage and supporting married girls - a mix of social, economic, and health interventions is needed. Much of the language of adolescent policy emphasizes the need to give adolescents information so they might "make better decisions." Yet, the life-altering decision to marry early, even illegally, and the choice of whom to marry are often not made by the adolescent, but by her mother, her father, or other senior members of her household. Evidence indicates that married girls may have less likelihood of acquiring accurate information or acting on it than their unmarried peers or married young women. The issues are thus not simply information and services, but the profound gender and generational power disparities that define married girls' experiences. Addressing these differences will entail special attention to ameliorating married girls' social isolation and promoting their empowerment.

\section{REFERENCES}

Achmad, Sulistinah Irawati and Sidney B. Westley. 1999. "Indonesian survey looks at adolescent reproductive health," Asia-Pacific Population and Policy no. 51.

Honolulu, HI: East-West Center.

Amin, Sajeda. 2004. "Child rights in Bangladesh," in Human Rights Report, Bangladesh, 2003. Dina Siddiqy (ed.), Dhaka: Ain-o-shalish Kendra. Forthcoming.

Amin, Sajeda, Ian Diamond, Ruchira Naved, and Margaret Newby. 1998. "Transition to adulthood of female garment-factory workers in Bangladesh," Studies in Family Planning 29(2): 185-200.

Amin, Sajeda, Simeem Mahmud, and Lopita Huq. 2002. "Baseline survey report on rural adolescents in Bangladesh.” Dhaka: Ministry of Women's Affairs, Government of Bangladesh.

Amin, Sajeda, and Nagah H. Al-Bassusi. 2004. "Education, wage work, and marriage: Perspectives of Egyptian working women," Journal of Marriage and the Family. In press.

Arends-Kuenning, Mary and Sajeda Amin. 2000. "The effects of schooling incentive programs on household resource allocation in Bangladesh," Policy Research Division Working Paper no. 133. New York: Population Council.

Brady, Martha. 2003. "Differentiating risk perception and protection needs of young women across the marital transition," draft background paper presented at the WHO/UNFPA/Population Council Technical Consultation on Married Adolescents, Geneva, 9-12 December.
Bruce, Judith. 2002. "Married adolescent girls: Human rights, health and developmental needs of a neglected majority," presented at the United Nations General Assembly Special Session on Children, New York, 8-10 May.

Bruce, Judith and Shelley Clark. 2003. "Including married adolescents in adolescent reproductive health and HIV/AIDS policy," background paper presented at the WHO/UNFPA/Population Council Technical Consultation on Married Adolescents, Geneva, 9-12 December.

Caldwell, J.C., P.H. Reddy, and Pat Caldwell. 1983. "The causes of marriage change in South India," Population Studies 37(3): 343-361.

Clark, Shelley. 2004. "Early marriage and HIV risks in Sub-Saharan Africa," Studies in Family Planning 35(3): 149-160.

Diop, Nafissatou J. and Jacqueline Cabral N'Dione. 2001. "Etude exploratoire du vecu des adolescentes mariees." Senegal: Population Council.

El-Zanaty, Fatma, Enas M. Hussein, Gihan A. Shawky, Ann A. Way, and Sunita Kishor. 1996. Egypt Demographic and Health Survey 1995. Calverton, MD: National Population Council (Egypt) and Macro International.

Erulkar, Annabel and Charles Onoka. 2003. Tabulations of data from the Adolescent Reproductive Health Information and Services Survey, Central Province, Kenya, 2001, unpublished.

Gage, Anastasia J. 1995. "Women's socioeconomic position and contraceptive behavior in Togo," Studies in Family Planning 26(5): 264-277.

—. 2000. "Female empowerment and adolescent demographic behaviour," in Harriet B. Presser and Gita Sen (eds.), Women's Empowerment and Demographic Processes: Moving Beyond Cairo. Oxford: Oxford University Press, pp. 186-203.

Gage-Brandon, Anastasia and Dominique Meekers. 1993. "The changing dynamics of family formation: Women's status and nuptiality in Togo," paper presented at the IUSSP Seminar on Women and Demographic Change in Sub-Saharan Africa, Dakar, 3-6 March.

George, Annie. 2002. "Embodying identity through heterosexual sexuality: Newly married adolescent women in India," Culture, Health and Sexuality 4(2): 207-222.

Graft, Auralice, Nicole Haberland, and Rachel Goldberg. 2003. "Addressing married adolescents' needs: A review of programmes," background paper prepared for the WHO/UNFPA/Population Council Technical Consultation on Married Adolescents, Geneva, 9-12 December. 
Haberland, Nicole, Elizabeth McGrory, and K.G. Santhya. 2001. "First-Time Parents Project: Supplemental diagnostic report, Baroda," unpublished.

Haberland, Nicole, Erica Chong, and Hillary Bracken. 2003. "Married adolescents: An overview," background paper presented at the WHO/UNFPA/Population Council Technical Consultation on Married Adolescents, Geneva, 9-12 December.

Hallman, Kelly. 2004. "Socioeconomic disadvantage and unsafe sexual behaviors among young women and men in South Africa," Policy Research Division Working Paper no. 190. New York: Population Council.

Hashemi, Syed, Sidney Ruth Schuler, and Ann P. Riley. 1996. "Rural credit programs and women's empowerment in Bangladesh," World Development 24(4): 635-653.

International Planned Parenthood Federation (IPPF) and International Women's Rights Action Watch. 2000. "Reproductive Rights 2000," wall chart. London: IPPF, www.ippf.org/newsinfo/pressreleases/yngpeople0006.htm.

Jejeebhoy, Shireen. 1995. Women's Education, Autonomy and Reproductive Behaviour: Experience from Developing Countries. Oxford: Clarendon Press.

- 2000. "Women's autonomy in rural India: Its dimensions, determinants, and the influence of context," in Harriet B. Presser and Gita Sen (eds.), Women's Empowerment and Demographic Processes: Moving Beyond Cairo. Oxford: Oxford University Press, pp. 204-238.

Khalil, K. 2003. "Study on hospital policies and practices regarding normal labor in Egypt: The el Galaa study." Cairo: Population Council.

Kishor, Sunita. 2000. "Empowerment of women in Egypt and links to the survival and health of their infants," in Harriet B. Presser and Gita Sen (eds.), Women's Empowerment and Demographic Processes: Moving Beyond Cairo. Oxford: Oxford University Press, pp. 119-156.

Kishor, Sunita and Kiersten Johnson. 2004. Profiling Domestic Violence: A Multi-Country Study. Calverton, MD: ORC Macro.

Madhavan, Sangeetha, Alayne Adams, and Dominique Simon. 2003. "Women's networks and the social world of fertility behavior," International Family Planning Perspectives 29(2): 58-68.

Malhotra, Anju. 1991. "Gender and changing generational relations: Spouse choice in Indonesia," Demography 28(4): 549-569.
Mason, Karen Oppenheim. 1998. "Wives' economic decision-making power in the family: Five Asian countries," in Karen Oppenheim Mason, Noriko O. Tsuya, and Minja Kim Choe (eds.), The Changing Family in Comparative Perspective: Asia and the United States. Honolulu, HI: East-West Center, pp.105-133.

Meekers, Dominique. 1992. "The process of marriage in African societies: A multiple indicator approach," Population and Development Review 18(1): 61-78.

Mensch, Barbara. 2003. "Trends in the timing of first marriage" presentation at the WHO/UNFPA/Population Council Technical Consultation on Married Adolescents, Geneva, 9-12 December.

Mensch, Barbara S., Judith Bruce, and Margaret E. Greene. 1998. The Uncharted Passage: Girls' Adolescence in the Developing World. New York: Population Council.

Miller, S., M. Cordero, A.L. Coleman, J. Figueroa, S. Brita-Anderson, R. Dabash, V. Calderone, F. Caceres, A.J. Fernandez, and M. Nunez. 2003. "Quality of care in institutionalized deliveries: The paradox of the Dominican Republic," International Journal of Gynecology and Obstetrics 82(1): 89-103.

Miller, Suellen and Felicia Lester. 2003. "Meeting the needs of the youngest first-time mothers," background paper presented at the WHO/UNFPA/Population Council Technical Consultation on Married Adolescents, Geneva, 9-12 December.

Ngondo a Pitshandenge, Iman. 1994. "Marriage law in sub-Saharan Africa," in Caroline Bledsoe and Gilles Pison (eds.), Nuptiality in Sub-Saharan Africa: Contemporary Anthropological and Demographic Perspectives. Oxford: Clarendon Press, pp. 117-129.

Olausson, Petra Otterblad, Sven Cnattingius, and Bengt Haglund. 1999. "Teenage pregnancies and risk of late fetal death and infant mortality," British Journal of Obstetrics and Gynaecology 106(2): 116-121.

Pateman, Carole. 1980. "Women and consent," Political Theory 8(2): 149-168.

Phipps, Maureen G. and MaryFran Sowers. 2002. "Defining early adolescent childbearing," American Journal of Public Health 92(1): 125-128.

Reynolds, H.W., E. Wong, C. Harcum et al. 2003. "Adolescents' use of maternal and child health services in developing countries," poster presented at the annual meeting of the Population Association of America, Minneapolis, 1-3 May. 
Saloucou, Lydia, Gisele Kabore, and Kotalama Traore. 2002. "Diagnostic study on the life experience of married adolescent girls, their economic opportunities, needs and reproductive health needs: The case of Natiaboani and Koare (Gourma Province)," unpublished final report. New York: Population Council.

Santhya, K.G. and Nicole Haberland. 2003. "Addressing the social context of married adolescent girls: The First-time Parents Project," presentation at the WHO/UNFPA/Population Council Technical Consultation on Married Adolescents, Geneva, 9-12 December.

Santhya, K.G. and Shireen Jejeebhoy. 2003. "Sexual and reproductive health needs of married adolescent girls," Economic and Political Weekly 38(41): 4370-4377.

Santhya, K.G., F. Ram, Nicole Haberland, S.K. Mohanty, Elizabeth McGrory, R.K. Sinha, Arup Das, and Anupa Mehta. 2003. "The gendered experience of married adolescent girls in India: Baseline findings from the FirstTime Parents Project," paper presented at the Second Asia and Pacific Conference on Reproductive and Sexual Health, Bangkok, 6-10 October.

Schuler, Sidney Ruth and Syed Hashemi. 1994. "Credit programs, women's empowerment, and contraceptive use in rural Bangladesh," Studies in Family Planning 25(2): 65-76.

Schuler, Sidney Ruth, Syed M. Hashemi, Ann P. Riley, and Shireen Akhter. 1996. "Credit programs, patriarchy and men's violence against women in rural Bangladesh," Social Science and Medicine 43(12): 1729-1742.
Schuler, Sidney Ruth, Syed M. Hashemi, and Shamsul Huda Badal. 1998. "Men's violence against women in rural Bangladesh: Undermined or exacerbated by microcredit programmes?" Development in Practice 8(2).

Singerman, D. and B. Ibrahim, 2001. The cost of marriage in Egypt: A hidden variable in the new Arab demography. Cairo Papers in Social Science. Cairo: American University in Cairo Press.

Steele, Fiona, Sajeda Amin, and Ruchira T. Naved. 2001. "Savings/credit group formation and change in contraception," Demography 38(2): 267-282.

Suran, Luciana and Sajeda Amin. 2004. "Does more dowry make life better for brides? A test of bequest theories of dowry in rural Bangladesh," presented at the annual meeting of the Population Association of America.

Thapa, Shyam and Vinod Mishra. 2003. "Mass media exposure among youth in urban Nepal," Asia-Pacific Population Journal 18(1): 5-28.

van de Walle, Étienne and Dominique Meekers. 1994. "Marriage drinks and kola nuts," in Caroline Bledsoe and Gilles Pison (eds.), Nuptiality in Sub-Saharan Africa: Contemporary Anthropological and Demographic Perspectives. Oxford: Clarendon Press, pp. 57-73.

Wolff, Brent, Ann Blanc, and Anastasia Gage. 2000. "Who decides? Women's status and negotiation of sex in Uganda," Culture, Health and Sexuality 2(3): 303-322. 


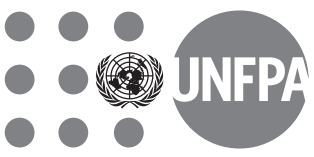

(2) Population Council 